\title{
Student as Child Labor in Agriculture Sector During Pandemic Covid-19
}

\author{
Faidah Azuz ${ }^{1, *}$, Aylee Christine A. Sheyoputri ${ }^{2}$, Fidaan Husein Azuz ${ }^{3}$, Mulono \\ Apriyanto ${ }^{4}$, Mieke Yustia Ayu Ratna Sari ${ }^{5}$, Dina Lusiana Setyowati ${ }^{6}$ \\ ${ }^{1}$ Bosowa University, Indonesia \\ ${ }^{2}$ Bosowa Universit, Indonesia \\ ${ }^{3}$ BAPPELITBANGDA Provinsi Sulawesi Selatan, Indonesia \\ ${ }^{4}$ Islamic University of Indragiri, Indonesia \\ ${ }^{5}$ Universitas Tulang Bawang, Lampung, Indonesia \\ ${ }^{6}$ Mulawarman University, Indonesia \\ ${ }^{*}$ Corresponding author.Email: faidah.azuz@universitasbosowa.ac.id
}

\begin{abstract}
This study aims to describe the condition of the students who work in agriculture sector during covid-19 pandemic; what the reason to work and what the parents' perception about students who work in farming. This research was done in Enrekang Regency of South Sulawesi Province, Indonesia. Respondents of this research were the parents of the students who worked in farming and students aged 13 to 15 who worked in farming during Covid-19 time. Data have been collected through interview, observation, and focused group discussion. This research shows that 63 percent of students started working in agriculture during pandemic, and 37 percent had been working before pandemic. The students' reason for being involved in farming was the immense difficulty to study online which was mainly caused by the limitation of online device and poor internet connection. This leads to children having more spare time during the day, which give them a chance to work. The parents did not mind their children working because the children could study at night and could provide additional household income.
\end{abstract}

Keywords: Student, child labor, agriculture sector, Covid-19.

\section{INTRODUCTION}

The impact of covid on the socio-economic life of the community is much more severe in rural areas compared to urban areas. Inadequate health services, inadequate access to transportation and information, and food scarcity have caused rural areas to suffer more severe consequences [1,2]. The impacts were caused by the government being forced to make various efforts to reduce the spread of the more severe Covid-19 in the long term.

One way of limiting the spread of Covid-19 is to reduce contact between humans including limitation of human mobilization. The government of Indonesia issues policy of online teaching and learning as response to this condition. On the other hand, the community in rural area takes benefit of this as to have more spare time for children at home, some of them then work in the agricultural sector. International Labor Organization estimates that globally 160 million children (63 million girls and 97 million boys) are employed, representing almost one in ten of all children in the world [3]. The Covid-19 health pandemic and the resulting economic and political labor market consequences are currently having a significant impact on people's lives and livelihoods. Unfortunately, impoverished families and their children are often the first to suffer, which can push many more vulnerable children into child labor situations [4].

Online learning is undeniably one of the ways to overcome the problem of the spread of covid. However, online learning in rural areas has caused several problems that were not taken into account at first. The barriers to distance learning are thought to be caused by the internet network that is not available, learning equipment that is not adequate, and expensive internet cost.

Rural communities who are generally low-income find it difficult to meet the main requirements for implementing online learning. The reality in low-income communities such as in the Philippines shows that low readiness is obtained in the low-income class of people 
living in villages [5]. This is due to the lack of equipment (computer) and internet connection. They are not ready to face online learning. This low income is exacerbated by the fact that the culture of saving as a savings fund in case something bad happens is not the culture of rural communities with small scale businesses $[6,7,8,9]$.

The situation of low income added by unsupportive internet networks, and online learning policy causes the school students not be fully able to study during the day. Study time is generally moved to the night and students will take turns using cell phones between sibling and parents for doing online learning. When students are not fully able to study during the day, they take advantage of that time to work in the agricultural sector. This is the starting point for school students to enter the agricultural sector job market during the Covid-19 period.

Various studies have been conducted around the aspects of children's health and learning barriers, but studies on what conditions occur when students enter the agricultural sector job market have not been studied further or at all. This study was conducted to examine the reasons why children enter the labor market, the types of plants that are suitable for them to work, and the responses of parents in the community of students who work. This kind of study has rarely been studied. This is the standing point of this research and also be the novelty of this research.

\section{METHOD}

Data collection: Data collection was carried out through interviewing respondents individually and focused group discussion to find a common understanding of students who work in the agricultural sector.

Unit of analysis and characteristics of respondents: The unit of analysis of this research is the household. There are two main respondents that are parents and working students. The characteristics of the respondents are determined as follow: the parents are those whose children are still in school and has been working in farming, while the working students are those who work in farming before and/or during pandemic. This research was done in village XYZ, Enrekang Regency, Indonesia. It is located in the center side of Sulawesi Island in the altitude around $500-1.000$ meter AMSL. From its geographic location, it can be seen that this region is suitable for planting red onion, corn, potato, and coffee (Figure 1).

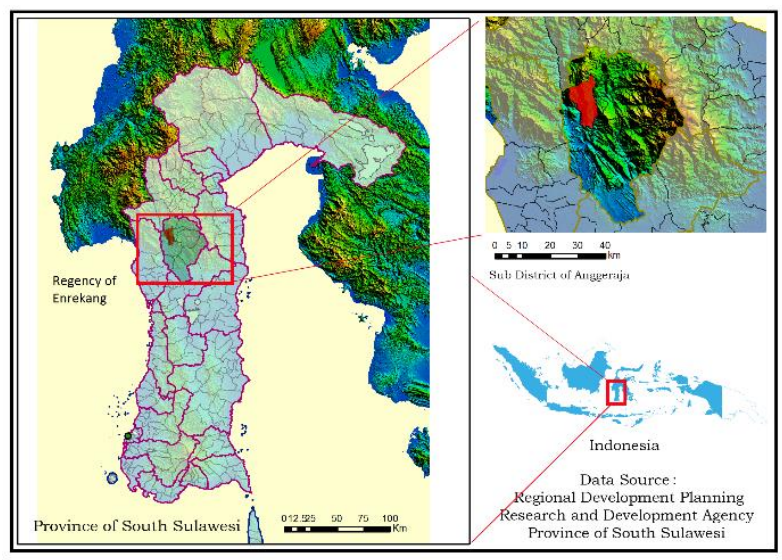

Figure 1. Map of research location

Population and samples: Based on the respondents' criteria, the population in this research is 73 heads of household whose children were working on farming and student from these households are 134 persons who worked in farming. From initial observations, it was found that the students could be categorized as students who had been working before and continued to work during the pandemic about 49 persons, and students who started working during the outbreak of the pandemic as many as 85 persons. The sample was determined 20 percent at simple random from the population so that the total sample of this research are parents as many as 14 persons, students who had been working before and during the pandemic as many as 10 persons, and student who started working since pandemic as many as 17 persons.

Analysis: This study uses combined analysis (mixed method). The information obtained from focused group discussion was analyzed using qualitative approach, while data that was obtained from the questionnaire was analyzed using quantitative approach by cross tabulation between variable.

\section{RESULT AND DISCUSSION}

\subsection{Condition of Working Students}

The government's policy of imposing online schools aimed at reducing the impact of the spread of Covid-19 has been adhered by all educational institutions at various levels and regions. This policy applies simultaneously regardless of the level of distribution partially in one area. This research found out that the policy also is obeyed by all educational institutions in village XYZ.

The teacher gave the lesson through WhatsApp application and the students did the assignment using cell phone then sent back the assignment to the teacher. One informant said that the communication through WhatsApp was good enough since the teacher could 
deliver lesson materials and assignments. The student could answer the question which was written on the paper, then took the photo of that assignment and sent it back to the teacher.

The way of communication to overcome the classical way of learning with the WhatsApp application is not completely successful, but this is the best way to do in areas which is far from urban areas. Face-to-face online applications such as zoom/google meet were never used due to network limitations, price for paying internet, and limited cell phone availability. The use of communication media such as WhatsApp which in China uses the WeChat application showed that in 7 (seven) rural areas, it supported learning activities up to 68 percent where parents and teachers communicated through WeChat media and actively provided daily assignments [10].

The online school applied by the government in rural areas does not seem to take into account the ability of the internet network, the availability of cell phones, and the high price of internet. The limitations of the online schools practice can be categorized into 4 barriers, namely personnel barriers, technical barriers, logistic barriers, and financial barriers. On the personal barrier, it is shown that not all parents can face technological obstacles in the application of distance learning, especially for parents who are at a low level of education [4]. As a result, online schools are seen as detrimental to rural students because they cannot learn effectively. This situation also occurs in rural areas of Ethiopia and Indonesia $[11,12]$, where the unused face-to-face school time provides opportunities for rural children to enter the available agricultural job market. The condition of the child labor market in South Sulawesi shows that there has been a very large increase in working students during the Covid-19 period, which was found to almost double (63 percent) compared to those who had been working before pandemic until the time this research was conducted. Information on the distribution of child labor in the agricultural sector by gender is presented in Table 1 .

Table 1. Working Student by The Time of Pandemic and Gender (\%)

\begin{tabular}{|l|r|r|r|}
\hline \multicolumn{1}{|c|}{$\begin{array}{c}\text { Working Time } \\
\text { Reference }\end{array}$} & \multicolumn{2}{|c|}{ Gender } & \multirow{2}{*}{ Total } \\
\cline { 2 - 3 } & Male & \multicolumn{1}{|c|}{ Female } & \\
\hline $\begin{array}{l}\text { Had been working before } \\
\text { Covid-19 }\end{array}$ & 42.1 & 25.0 & 37.0 \\
\hline $\begin{array}{l}\text { Started working during } \\
\text { Covid-19 }\end{array}$ & 57.9 & 75.0 & 63.0 \\
\hline Total & 100.0 & 100.0 & 100.0 \\
\hline
\end{tabular}

$\mathrm{n}$ Male $=19 ; \mathrm{n}$ Female $=8$

Source: Processed from primary data, 2021.

The percentage of female students entering the agricultural sector job market is three times what they were in the labor market before Covid-19. This situation is different from male students who had been working before Covid-19 and who started working during Covid19. With an increase in the percentage of students who work quite high, this study succeeded in showing that: (1) the implementation of distance learning has provided opportunities for the opening of the job market for school children (2) what the government is trying to achieve that is social distancing restrictions is not being met in the realm of education. However, the flock then shifts from the classroom to the agricultural sector job market. The flock of children turned into the labor market has typical reasons, one of which is the free time due to the implementation of online schools. Other reasons can be seen in Table 2.

Table 2. The Reasons of Working Students and Type of Crop (\%)

\begin{tabular}{|l|r|r|}
\hline \multirow{2}{*}{$\begin{array}{c}\text { Reason to Work and Type } \\
\text { of Crop }\end{array}$} & \multicolumn{2}{|c|}{ Gender } \\
\cline { 2 - 3 } & Male & Female \\
\hline Reason to Work & 52.6 & 25.0 \\
\hline Have time & 21.1 & 12.5 \\
\hline Requested by neighbor & 26.3 & 62.5 \\
\hline $\begin{array}{l}\text { To support parents } \\
\text { financially }\end{array}$ & 100.0 & 100.0 \\
\hline Total & 26.3 & 12.5 \\
\hline Type of Crop & 47.4 & 87.5 \\
\hline Corn & 26.3 & 0.0 \\
\hline Red Onion & 100.0 & 100.0 \\
\hline Corn + Red Onion
\end{tabular}

$\mathrm{n}$ Male $=19 ; \mathrm{n}$ Female $=8$

Source: Processed from primary data, 2021.

For the reason why students enter the job market, it can be seen that proportionally the male students take advantage of the available time while more than half of the girls give reason to help their parents. It seems that what crosses the mind of the girls when there is a job opportunity is their desire to contribute to the economic aspect of the household, while boys see that as more job opportunities because of the availability of free time in their daily lives.

Due to physical abilities (power) that are not like adults, not all jobs in the agricultural sector can be entered by children. In the research area, there are four dominant types of plants, that are coffee, potato, corn, and red onion. From the results of in-depth interviews, it is known that school children cannot work in coffee farming because the location of the plantation is too far from the village. Although the location of the potato gardens is in the vicinity of the village, farming activities do not require additional labor because the maintenance is enough to be carried out by a few adult workers. It is different with onion farming which requires a lot of labor especially during maintenance, drying, and transportation from the garden to the roadside. These three activities in the red onion farming business became 
the target of the job market for children, including students.

Information presented in Table 2 shows that the concentration of male and female students is in onion farming. However, if we look further, it can be seen that the proportion of almost all female students working in onion farming (87.5 percent), while the male students are quite balanced on corn and onion farming activities. This study also finds that very few girls worked in corn farming. The main reason given is that working in corn farming requires a lot of physical exertion so that only a few girls were able to work in corn farming.

Corn and red onion are annual crops which harvest period is not more than a year. A limited survey conducted in Ugandan village shows that the impact of Covid-19 on agriculture shows that workers in the agriculture sector survive longer because they are small farming families and producers of non-essential commodities. This was due to an increase in their child labor during the 12 months school closure period, thereby reducing labor costs. Children are involved with low wages, slow time to pay, not even paid at all $[13,14]$.

In Table 2 it is shown also the reasons for working distinguished by gender. This study also finds that those reasons are related and tied to the pandemic period. In Table 3 it is clear that most of the students who worked during the pandemic were caused by their free time due to distance learning.

Table 3. Working Student and Reason to Work (\%)

\begin{tabular}{|l|c|c|c|}
\hline \multirow{2}{*}{$\begin{array}{c}\text { Working Time } \\
\text { Reference }\end{array}$} & \multicolumn{3}{|c|}{ Reasons to Work } \\
\cline { 2 - 4 } & Saving & $\begin{array}{c}\text { Give to } \\
\text { Parents }\end{array}$ & $\begin{array}{c}\text { Personal } \\
\text { Allowance }\end{array}$ \\
\hline $\begin{array}{l}\text { Had been working } \\
\text { before Covid-19 }\end{array}$ & 66.7 & 16.7 & 44.4 \\
\hline $\begin{array}{l}\text { Started working } \\
\text { during Covid-19 }\end{array}$ & 33.3 & 83.3 & 55.6 \\
\hline Total & 100.0 & 100.0 & 100.0 \\
\hline $\mathrm{N}=27$
\end{tabular}

Source: Processed from primary data, 2021.

The reason of the students who had been working before Covid-19 period were concentrated on saving money activities (67 percent), while those who had just entered the agricultural sector job market during Covid19 most of their income was given to their parents. In indepth interviews it was found that the reasons for saving and giving income to the parents are actually two very similar things. Savings are ultimately used to meet the student's needs such as buying a cell phone or other school needs, while giving income to the parents is a clear indication of the contribution of child labor to overall household income. Saving to meet their own needs according to students who work is their way of reducing the burden of their parents. Reducing parents' burdens implicitly can be understood as another way of household members contributing to the household's income. The use of wages from work in the agricultural sector for personal allowance/snacking is more widely used by children who have just entered the labor market.

\subsection{Parents' Responses}

Parents' views on working children were obtained from in-depth interviews and focused group discussion. The result of this study shows that the parents view the children who had been working before the pandemic period as a life lesson to train children to "love" agriculture because they are heirs to their parents' farmland. However, whether this parent's desire will continue to be consistent or not is an entry point for conducting research on other topics.

Apart from being an arena for practicing "loving" agriculture, the parents whose children work see that the time available as consequence of distance learning also gives students an opportunity to work in the agricultural sector. Another thing that was revealed in the focused group discussion with parents was that the children are free to manage their finances and thus they can buy what they want because of the wages they get from the job. Some parents said that they can fulfil their children's basic needs for school, but their children's appetite for buying things that are trending will be met through the savings they have. From the in-depth interview it is also revealed that when students buy their needs, they have actually reduced their parents' burden in fulfilling children's needs. This is the urgency of a child's involvement in working and by that, the parents have rolled out a red carpet for them to enter the job market. In other words, this research strongly emphasizes that students who work are accepted by their parents and the students themselves as an effort to contribute to household income in general.

\section{CONCLUSION}

This study that is conducted in highland rural areas shows that online learning or distance learning is not fully accessible to students. The free time during the day that should be filled with online learning is used by students to work in the agricultural sector. The parents support the entry of students into the agricultural sector job market. The social distancing announced by the government only applies to distance learning, but it doesn't work when students enter the agricultural sector job market. This research also finds that working school children contribute to the family income in general.

\section{AUTHORS' CONTRIBUTIONS}

FA conceived the original idea, designed and conducted the study. FHA drafted the manuscript, 
searched the literatures, and designed the map. All authors discussed the results, provided critical feedback, and contributed to the final manuscript.

\section{ACKNOWLEDGMENTS}

The authors thank Sitti Nurjannah, an undergraduate student of Agribusiness Study Program, Agriculture Faculty, Bosowa University, for assisting data retrieval in the field and helping to communicate with local people.

\section{REFERENCES}

[1] Ali, A., Ahmed, M. and Hassan, N., 2020. Socioeconomic impact of COVID-19 pandemic: Evidence from rural mountain community in Pakistan. Journal of Public Affairs, p.e2355.

[2] Mueller, J.T., McConnell, K., Burow, P.B., Pofahl, K., Merdjanoff, A.A. and Farrell, J., 2021. Impacts of the COVID-19 pandemic on rural America. Proceedings of the National Academy of Sciences, 118(1).

[3] International Labour Organization, 2020. Child Labour: Global Estimates 2020, Trends and the Road Forward.

[4] Abuhammad, S. (2020). Barriers to distance learning during the COVID-19 outbreak: A qualitative review from parents' perspective. Heliyon, 6(11), e05482.

[5] Clemen, I. G., Ali, H., Abdulmadjid, A.-N., \& Jabbar, J. H. (2021). Education During COVID-19 Era: Readiness of Students in a Less-Economically Developed Country for E-Learning. IMCC Journal of Science 2021, 1, 94-101.

[6] Obalola, O.T., Audu, R.O. and Danilola, S.T., 2018. Determinants of Savings among Smallholder Farmers in Sokoto South Local Government Area, Sokoto State, Nigeria. Acta agriculturae Slovenica, 111(2), pp.341-347.

[7] Antwi, M. and Chagwiza, C., 2019. Factors influencing savings among land reform beneficiaries in South Africa. International Journal of Social Economics.

[8] Aidoo-Mensah, D., 2019. Determinants of rural household savings behaviour: The case of tomato farmers in Ghana. Review of Agricultural and Applied Economics (RAAE), 22(1340-2019-3705), pp.55-70.

[9] Ruedas, M.Y.A.D. and Guico, M.J., 2021. Saving Pattern Of Small-Scale Women Rice Farmers In San Jose, Occidental Mindoro. Journal of Asian Rural Studies, 5(1), pp.48-55.
[10] Wang, H., Dill, S. E., Zhou, H., Ma, Y., Xue, H., Sylvia, S., Smith, K., Boswell, M., Medina, A., Loyalka, P., Abby, C., Friesen, D., Rose, N., Guo, Y., \& Rozelle, S. (2021). Health, economic, and social implications of COVID-19 for China's rural population. Agricultural Economics (United Kingdom), 52(3), 495-504.

[11] Belay, D.G., 2020. COVID-19, Distance Learning and Educational Inequality in Rural Ethiopia. Pedagogical Research, 5(4).

[12] Lase, D., Zega, T.G.C. and Daeli, D.O., 2021. Parents' perceptions of distance learning during Covid-19 pandemic in rural Indonesia. Journal of Education and Learning (EduLearn).

[13] Pattenden, J., Campling, L., Castañón Ballivián, E., Gras, C., Lerche, J., O’Laughlin, B., Oya, C., PérezNiño, H., \& Sinha, S. (2021).

[14] Berge, M. P. van den. (2011). Child Labour in Traditional and Commercial Agriculture. In GK. Lieten (Ed.), Hazardous Child labor in latin America. 